\title{
ПІДВИЩЕННЯ СТІЙКОСТІ КАБЕЛІВ ДО ПОШИРЕННЯ ПОЛУМ'Я ШЛЯХОМ ОБЛИЦЮВАННЯ МЕТАЛЕВОГО КАБЕЛЬНОГО КОРОБУ РЕАКТИВНИМ ВОГНЕЗАХИСНИМ МАТЕРІАЛОМ
}

С. В. Новак ${ }^{1}$, канд. техн. наук, ст. наук. співроб., В. Л. Дріжд², канд. техн. наук,

П. О. Іллюченко ${ }^{1 *}$

${ }^{1}$ Український науково-дослідний інститут цивільного захисту, Україна

${ }^{2}$ Науково-виробниче підприємство «Спецматеріали», Україна

\section{ІНФОРМАЦІЯ ПРО СТАТТЮ}

Надійшла до редакції: 23.05.2019

Пройшла рецензування: 25.06.2019

\section{КЛЮЧОВІ СЛОВА:}

\section{вогневий вплив, кабель,} кабельний короб, поширення полум'я, реактивний вогнезахисний матеріал, спучення.

\begin{abstract}
АНОТАЦІЯ
Наведено результати дослідження стійкості до поширення полум'я кабелів, прокладених у металевому кабельному коробі, внутрішня поверхня якого покрита реактивним вогнезахисним матеріалом. Застосовано методику дослідження, яка ґрунтується на положеннях ДСТУ EN 60332-3-10 та ДСТУ EN 60332-3-22. Сутність цієї методики полягає в тому, що на пучок кабелів категорії A, класу нестійких до поширення полум'я, розташований всередині металевого кабельного коробу, через прямокутний отвір в кришці коробу протягом 40 хв діють полум'ям двох спеціальних стрічкових пальників. Після припинення впливу цього полум'я визначають довжину звугленої частини кабелів і порівнюють її з граничним значенням, яке становить 1,5 м. За результатами дослідження встановлено особливості процесу поширення полум'я по кабелях, прокладених у металевому кабельному коробі, внутрішня поверхня якого покрита реактивним вогнезахисним матеріалом. Визначено конструктивне рішення, яке забезпечує обмеження поширення полум'я по кабелях, прокладених у металевому кабельному коробі, в межах приміщення, де виникла пожежа. Встановлено напрям подальших досліджень, які орієнтовані на виявлення впливу об'ємного коефіцієнту спучення реактивного вогнезахисного матеріалу, яким покрито внутрішню поверхню металевого кабельного коробу, на стійкість кабелів до поширення полум'я, а також впливу параметрів металевого кабельного коробу, у тому числі без вогнезахисного покриття, на інтенсивність поширення полум'я вздовж кабелів.
\end{abstract}

Bcmyn. Відповідно до Регламенту (ЄС) № 305/2011 [1], Технічного регламенту будівельних виробів, будинків і споруд [2] та державних будівельних норм ДБН В.1.2-7 [3] однією з основних вимог до будівель і споруд $€$ обмеження поширення в них вогню під час пожежі. Метою обмеження поширення вогню на будівельних об'єктах є забезпечення сповільнення розвитку пожежі, щоб надати достатнього часу для евакуації людей, які перебувають поблизу та/або на відстані від місця виникнення пожежі, а також надання можливості пожежно-рятувальним підрозділам контролювати пожежу, поки вона не набула значного розвитку.

Положення щодо обмеження поширення вогню в межах приміщення, де виникла пожежа, спрямовані на обмеження швидкого залучення до горіння будівельних виробів на ранній стадії пожежі i обмеження сприяння будівельних виробів повному розвитку пожежі в приміщенні, де вона виникла. Таким чином, відповідні будівельні вироби повинні мати певні характеристики реакції на вогонь. Ці характеристики оцінюють в умовах дії низки теплових впливів, починаючи від впливу невеликого полум'я (типу сірника), впливу, що моделює пожежу всередині приміщення (поодинокий предмет, що горить, наприклад, меблі), до впливу розвиненої пожежі [3]. Стосовно ізольованих проводів та кабелів (далі - кабелів), то їхньою основною характеристикою реакції на вогонь $є$ стійкість до поширення полум'я, за якою їх поділяють на стійкі і нестійкі до поширення полум'я [4]. У низці нормативних документів і будівельних норм, зокрема в $[5,6]$, застосовують інші терміни і кабелі поділяють на такі, що не поширюють горіння і такі, що його поширюють. Зазначену характеристику реакції на вогонь оцінюють в умовах дії на кабелі пальників певної потужності. Під час цих випробувань визначають довжину звугленої частини кабелів і порівнюють її з допустимим значенням [4]. Для забезпечення виконання основної вимоги до будівель і споруд щодо обмеження поширення в 
них вогню під час пожежі, в державних будівельних нормах, зокрема в [7, 8], наведено положення щодо застосування на будівельних об'єктах кабелів, які є стійкими до поширення полум'я. Для забезпечення цієї стійкості застосовують конструктивні рішення, які полягають у використанні спеціальних пластикатів для оболонки кабелів [9] або покритті поверхні кабелів вогнезахисними матеріалами [10]. Однак ці конструктивні рішення не завжди можливо впровадити на практиці для забезпечення обмеження поширення вогню в межах приміщення, де виникла пожежа. Зокрема, на експлуатованих будівельних об'єктах у ряді випадків є проблематичним провести заміну існуючих нестійких до поширення полум'я кабелів на стійкі кабелі або виконати вогнезахисне облицювання їхньої оболонки. Крім того, наявність вогнезахисного покриття на кабелях, в певних умовах призводить до необхідності зменшення струмового навантаження кабелів для забезпечення ї номінального температурного режиму експлуатації. Тому актуальною задачею $\epsilon$ визначення інших рішень, які забезпечують обмеження поширення вогню (полум'я) по кабелях в межах приміщення, де виникла пожежа.

Аналіз літературних даних та постановка проблеми. Приналежність кабелів (з вогнезахисним покриттям або без нього) до класу стійких до поширення полум'я визначають шляхом випробувань відповідно до положень, наведених в ДСТУ 4809 [4]. При цьому випробування одинично прокладених кабелів на поширення полум'я проводять згідно 3 ДСТУ ЕN 60332-1-2 [11] та ДСТУ ЕN 60332-13 [12]. Під час цих випробувань зразки кабелю довжиною $(620 \pm 5)$ мм розташовують вертикально i піддають впливу полум'я потужністю 1 кВт, створеного газовим пальником. Тривалість дії полум'я залежить від діаметра кабелю і становить від 60 с до 480 с. Після відведення пальника визначають тривалість самостійного горіння кабелю та довжину необвуглених зон кабелю. Кабель відносять до класу стійких до поширення полум'я за умов, що довжина необвуглених зон не менша ніж 50 мм, тривалість самостійного горіння не більша ніж 30 с і відсутні краплі/частки із запалювальною здатністю [4].

Для визначення стійкості до поширення полум'я кабелів, прокладених у пучках, випробування проводять за ДСТУ ЕN 60332-3 [13]. Під час цих випробувань пучок кабелів довжиною (3500 \pm 50) мм закріплюють на драбині, що розміщена у вертикальному положенні у випробувальній камері. Цей пучок кабелів піддають впливу полум'я спеціального стрічкового пальника (пальників) потужністю 20,5 кВт. Тривалість дії полум'я залежить від об'єму неметалевих матеріалів на 1 метрі зразка i становить під 20 хв до 40 хв. Під час випробувань спостерігають за станом кабелів під дією випробувального полум'я і визначають наявність чи відсутність поширення полум'я по кабелях або за межі випробувальної камери через іiі вихідний отвір. Після припинення впливу випробувального полум'я і охолодження кабелів визначають довжину звугленої частини пучка кабелів. Кабелі, прокладені у пучках, відносять до класу стійких до поширення полум'я за умов, що довжина обвугленої частини пучка кабелів не перевищує 1,5 м [4].

Результати дослідження поширення полум'я по одинично прокладених кабелях i кабелях, прокладених у пучках, надано у роботах [14, 15]. У роботі [14] наведено дані щодо впливу діаметру і кількості жил кабелів, матеріалу, 3 якого їх зроблено, та інших параметрів на поширення полум'я по одинично прокладених електричних кабелях. Встановлено, що екрановані кабелі поширюють полум'я у значно більшій мірі, ніж їх неекрановані аналоги. Для екранованих кабелів максимальна довжина обвуглювання росте пропорційно діаметру жили. Відсутні значні відмінності у поширенні полум'я для кабелів, що відрізняються один від одного тільки матеріалом, 3 якого зроблено їхні жили. Ці дослідження проведено із застосуванням національного стандарту Польщі PN-EN 60332 1-2:2010, який відповідає ДСТУ ЕN 60332-1-2 [11]. За результатами дослідження [15] встановлено, що на процес поширення полум'я по кабелях, прокладених у пучках, впливає не тільки пожежне навантаження кабелів, а і їхнє взаємне розташування. Через це було зроблено висновок про необхідність проведення випробувань на стійкість до поширення полум'я кабелів із зазором або без нього залежно від типу кабелів і характерного способу їхнього прокладання в кабельних спорудах.

У роботі [16] наведено результати дослідження поширення полум'я по електричних кабелях, розташованих на горизонтальних кабельних лотках. Експерименти проведено із використанням кабельних лотків, розташованих один над одним на стіні в обмеженому приміщенні, 3 різними конструкціями кабелів. Вогневому впливу піддавали кабель, розташований у нижньому 
лотку. Потім відбувалося займання кабелю на нижній поверхні верхнього лотка. Встановлено, що для кабелів, щільно упакованих, спостерігається поширення полум'я на нижній поверхні кабельного лотка і збільшення втрати маси кабелів.

У роботі [17] представлено результати чисельного моделювання із застосуванням CFD технології для прогнозування поширення вогню (полум'я) по кабельних лотках. У моделі застосовано п'ять горизонтальних лотків (кожний довжиною 2,4 м і шириною 0,45 м), які розташовані на стіні на відстані 0,3 м один над одним. Кожен лоток містить 49 електричних ПВХ кабелів. Запалювання здійснювали за допомогою пропанового пальника 80 кВт, розташованого на 0,2 м нижче нижнього лотка. За результатами моделювання отримано дані щодо розподілу температури і зон поширення полум'я на кабелях i лотках для обраного сценарію вогневого впливу.

Слід зазначити, що у наведених вище роботах не розглянуто методи випробувань i результати дослідження поширення полум'я по кабелях для всіх способів їхнього прокладання, які використовують на практиці, зокрема - в кабельних коробах. Існуючі методи випробувань на стійкість кабелів до поширення полум'я можуть бути застосовані при їхньому прокладанні на драбинах та лотках і за цими методами визначають приналежність кабелів до класу стійких до поширення полум'я. Однак, у
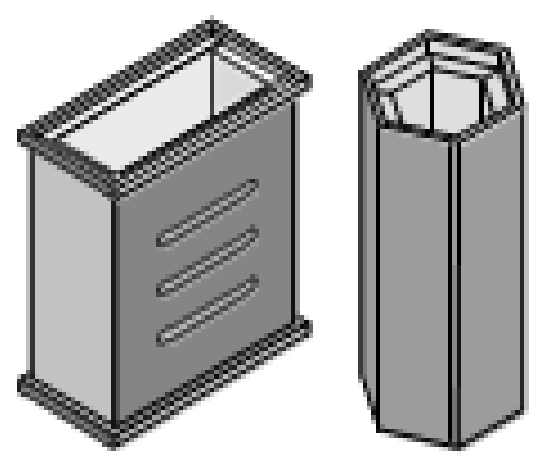

Рисунок 1. - Зображення кабельних муфт (а) і кабельної проходки через стіну із застосуванням

Рисунок 1. - Зображення кабельних муфт (а) і кабельної проходки через стіну із застосуванням кабельної муфти (б) разі прокладання кабелів у коробах, оцінювання обмеження поширення вогню (полум'я) по кабелях в межах приміщення, де виникла пожежа, на нашу думку, слід проводити за методами, які враховують реальні умови їхнього прокладання.

Для обмеження поширення вогню в межах приміщення, де виникла пожежа, в будівельних нормах [7, 8] наведено вимогу щодо застосування на будівельних об'єктах стійких до поширення полум'я кабелів. У той же час такої вимоги не висувається для кабелів, які застосовують у кабельних проходках [18]. Для цих проходок основною вимогою $\epsilon$ забезпечення обмеження поширення вогню через стіни і перекриття за межі приміщення, де виникла пожежа. Для виконання цієї вимоги, для кабельних проходок, використовують різні конструктивні рішення, які забезпечують збереження огороджувальної функції проходок під час розвинутої пожежі [18]. Серед них $\epsilon$ конструктивне рішення, в якому застосовують кабельні муфти. Кабельні муфти складаються 3 металевого каркаса 3 внутрішніми шарами iз реактивного вогнезахисного матеріалу (рис. 1 [18]). При тепловому впливі під час пожежі цей вогнезахисний матеріал спучується, утворюючи теплоізоляційний шар, який перешкоджає поширенню вогню (у тому числі і поширенню полум'я по кабелях) і зменшує інтенсивність теплопередачі до поверхні кабельної проходки, яка протилежна тепловому впливу.

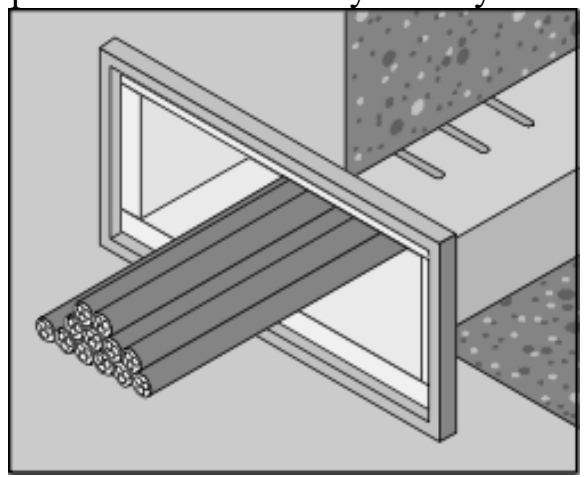

Рисунок 1. - Зображення кабельних муфт (а) і кабельної проходки через стіну із застосуванням (⿻)

Зазначене для кабельних проходок конструктивне рішення може бути застосоване i для забезпечення обмеження поширення полум'я по кабелях, прокладених у металевих кабельних коробах, в межах приміщення, де виникла пожежа. Однак на підтвердження цієї гіпотези (припущення) не наведені відповідні результати досліджень. Тому $є$ підстави вважати, що невизначеність впливу характеристик реактивного вогнезахисного покриття на внутрішній поверхні металевих кабельних коробів на стійкість кабелів до поширення полум'я обумовлює проведення досліджень у цьому напрямку.

Мета і завдання дослідження. Метою роботи $\epsilon$ визначення прийнятності конструктивного рішення, яке полягає у застосуванні реактивного вогнезахисного 
матеріалу на внутрішній поверхні металевого кабельного коробу, забезпечувати обмеження поширення вогню (полум'я) по кабелях, розташованих у цьому коробі, в межах приміщення, де виникла пожежа.

Для досягнення цієї мети були поставлені такі завдання:

- розробити методику дослідження стійкості до поширення полум'я кабелів, прокладених у кабельному коробі з внутрішнім шаром із реактивного вогнезахисного матеріалу;

- встановити особливості процесу поширення полум'я по кабелях, прокладених у металевому кабельному коробі, внутрішня поверхня якого покрита реактивним вогнезахисним матеріалом;

- визначити стійкість до поширення полум'я кабелів, прокладених у металевому кабельному коробі 3 внутрішнім шаром із реактивного вогнезахисного матеріалу.

Методи досліджсння стійкості до поширення полум'я кабелів, прокладених у металевому кабельному коробі. Для дослідження застосовано методику, яка грунтується на положеннях ДСТУ ЕN 60332-310 [19] та ДСТУ ЕN 60332-3-22 [20].

Сутність цієї методики полягає в тому, що на пучок кабелів категорії А (номінальний об'єм неметалевих матеріалів 7,0 дм $\left.{ }^{3} / \mathrm{M}\right)$, класу нестійких до поширення полум'я за 4.2 ДСТУ 4809 [4], розташований всередині металевого кабельного коробу, через прямокутний отвір в кришці коробу протягом 40 хв діють полум'ям двох спеціальних стрічкових пальників потужністю 20,5 кВт кожен. Кабельний короб, внутрішні поверхні якого покрито реактивним вогнезахисним матеріалом, закріплюють на широкій випробувальній драбині, що розміщена у вертикальному положенні у випробувальній камері. Усередині короба на певних рівнях по його висоті встановлюють термопари для визначення температури газового середовища біля поверхні кабелів на різних відстанях від пальників.

Під час випробування вимірюють температуру газового середовища біля поверхні кабелів, спостерігають за станом кабелів під дією випробувального полум'я і визначають наявність чи відсутність поширення полум'я по внутрішньому об'єму короба або за межі випробувальної камери через її вихідний отвір.

Після припинення випробування (припинення прикладання випробувального полум'я i охолодження коробу та кабелів) проводять огляд коробу на наявність отворів прогорання i після зняття кришки короба визначають довжину звугленої частини пучка кабелів. Довжину звугленої частини пучка кабелів вимірюють по висоті від нижнього краю пальників до межі зони звуглювання. Цю межу визначають таким чином: на поверхню кабелів натискають гострим предметом, наприклад лезом ножа, і місце, де фіксується зміна пружної поверхні на крихку (ламку), вважають межею зони звуглювання.

Якщо при випробуванні полум'я не поширювалося по внутрішньому об'єму короба та не сягало за межі випробувальної камери через вихідний отвір, не виявлено отвору прогорання коробу, розташованого на відстані більше ніж 1,5 м від нижнього краю пальників, i довжина звугленої частини пучка кабелів в коробі не перевищує 1,5 м, то вважають, що пучок кабелів, розташований всередині коробу, внутрішня поверхня якого покрита реактивним вогнезахисним матеріалом, не поширюе полум'я.

Для перевірки того, що кабелі, які були використані при випробуванні, належать до класу нестійких до поширення полум'я за 4.2 ДСТУ 4809 [4], проводять випробування (без застосування коробу) пучка кабелів категорії А за ДСТУ ЕN 60332-3-22 [20].

Для отримання даних щодо характеристик матеріалів, які можуть мати вплив на процес поширення полум'я в кабельному коробі, проводять визначення коефіцієнту спучення за ДСТУ-Н-П Б В.1.1-29 [21] та теплоти згоряння за ДСТУ Б EN ISO 1716 [22] реактивного вогнезахисного матеріалу і кабелів, які можна застосовувати при випробуванні на поширення полум'я.

Результати дослідження стійкості до поширення полум'я кабелів, прокладених у металевому кабельному коробі. При дослідженні стійкості до поширення полум'я застосовували пучок кабелів категорії А за ДСТУ ЕN 60332-3-22 [20] (нормований об'єм горючого навантаження 7 дм $^{3}$ на погонний метр), сформований з 5 відрізків завдовжки 3500 мм кабелю марки АВБбШв $3 \times 150+1 \times 70$ мм $^{2}$ та 3 відрізків завдовжки 3500 мм кабелю марки АВВГ $4 \times 185$ мм $^{2}$, який прокладали в суцільний сталевий кабельний короб (зі знімною кришкою) з внутрішнім перерізом 500 мм х 60 мм і товщиною стінок і кришки 1,0 мм (рис. 2). Внутрішню поверхню коробу було покрито шаром із реактивного вогнезахисного матеріалу «Ендотерм ХТ-150» [23], середньою товщиною 0,89 мм. 
Закріплення кабелів до дна коробу здійснено чотирма сталевими перемичками за допомогою шпильок та гайок $з$ діаметром різі 6 мм. Перемички виконані 3 сталевих стрічок товщиною 2,0 мм та шириною 75 мм. Відстань між кабелями становила від 15 мм до 20 мм. Для улаштування кожної перемички задіяні чотири короткі внутрішні та три довгі наскрізні шпильки. Для закріплення кришки короба застосовано довгі шпильки. В нижній частині кришки короба, в місці впливу випробувального полум'я, вирізано прямокутний отвір розмірами 480 мм $\times 180$ мм (рис 3, а). Усередині короба встановлювали термопари $\mathrm{T}_{1}-\mathrm{T}_{9}$ (рис. 2) для визначення температури газового середовища біля поверхні кабелів на різних відстанях від пальників. Вертикально розташований короб з кабелями було закріплено на широкій випробувальній драбині згідно 3 ДСТУ ЕN 60332-3-22 [20].

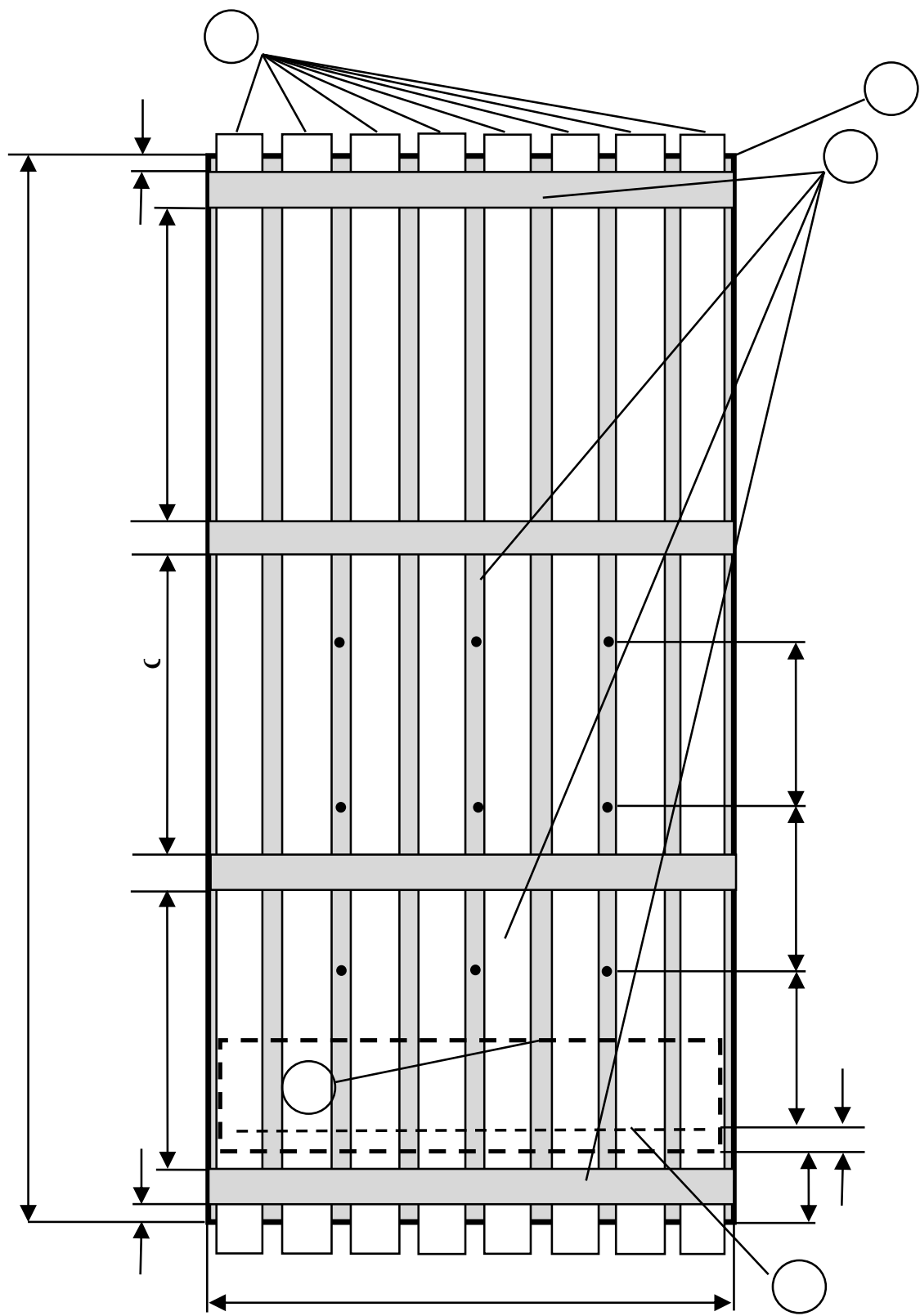

1 - кабелі; 2 - короб; 3 - перемички; 4 - проекція отвору у кришці коробу для прикладання випробувального полум'я; 5 - уявна лінія проекції нижнього краю пальників; $\mathrm{T}_{1}-\mathrm{T}_{9}-$ термопари

Рисунок 2 - Схема розміщення кабелів і термопар у коробі 


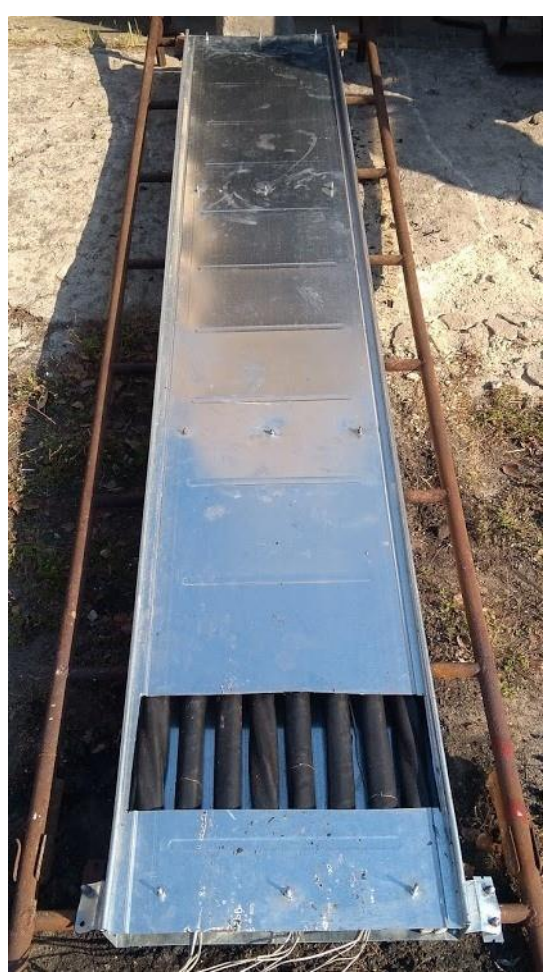

a

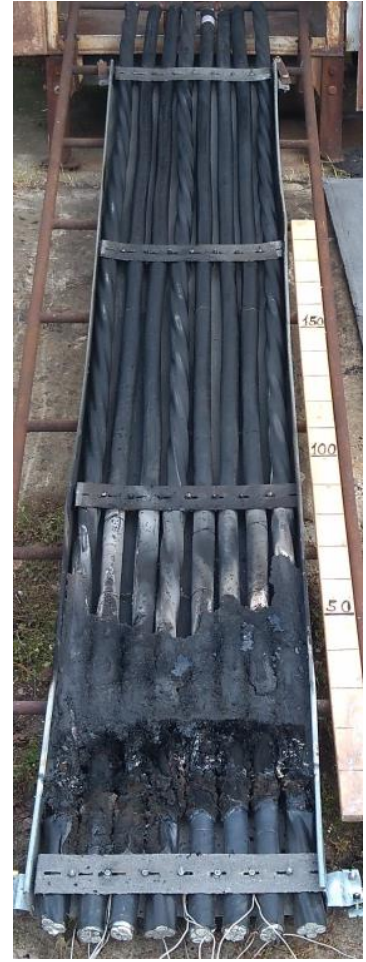

б

Рисунок 3 - Зовнішній вигляд короба з кабелями: а - до прикладання випробувального полум'я; б - після припинення прикладання випробувального полум'я, охолодження коробу та кабелів і зняття кришки короба

Через отвір в кришці коробу кабелі протягом 40 хв піддавали впливу полум'ям двох спеціальних стрічкових пальників потужністю 20,5 кВт кожен. За результатами візуальних спостережень за поведінкою кабелів і короба встановлено, що під час випробування полум'я покривало всю площу отвору в кришщі коробу, а за межами вихідного отвору камери полум'я не спостерігалося. Після припинення подавання газу до пальників, протягом 3 хв спостерігалося самостійне полуменеве горіння кабелів в межах отвору в кришці коробу. За результатами огляду коробу та кабелів після їхнього охолодження і зняття кришки короба (рис. 3, б) встановлено, що пошкодження цілісності коробу (прогорання отворів в стінках коробу, розділення стиків елементів коробу) не відбулося. Максимальна довжина обвугленої частини кабелів становить 640 мм, що менше граничного значення 1500 мм. У зоні звуглювання має місце збільшення товщини оболонок кабелів на 5-15 мм. Внутрішній простір коробу в зоні впливу полум'я пальників і вище на 190-250 мм від верхньої границі отвору у кришці коробу для прикладання випробувального полум'я заповнено шаром спученого вогнезахисного матеріалу.
За результатами вимірювання температури визначено, що максимальне підвищення температури газового середовища біля поверхні кабелів має місце на 15-25 с дії випробувального полум'я. При цьому, максимальне значення температури становить $742^{\circ} \mathrm{C}$ на відстані 500 мм від пальників $\left(\mathrm{T}_{1}\right.$, рис. $2,4)$. У подальшому спостерігається зменшення температури (в основному впродовж 1-2 хв випробування) i подальше iii монотонне незначне підвищення (до моменту припинення діï джерела запалювання) до максимального значення $262^{\circ} \mathrm{C}\left(\mathrm{T}_{3}\right.$, рис. 2,4$)$. Після припинення подавання газу до пальників температура монотонно зменшується.

За результатами випробування, проведеного за ДСТУ ЕN 60332-3-22 [20] (без застосування коробу), встановлено, що кабелі, які були використані при дослідженні, не відповідають вимогам цього стандарту i належать до класу нестійких до поширення полум'я за 4.2 ДСТУ 4809 [4]. На 30-ій хвилині цього випробування полум'я поширилося за межі верхнього отвору випробувальної камери (рис. 5) і кабелі було повністю пошкоджено. 


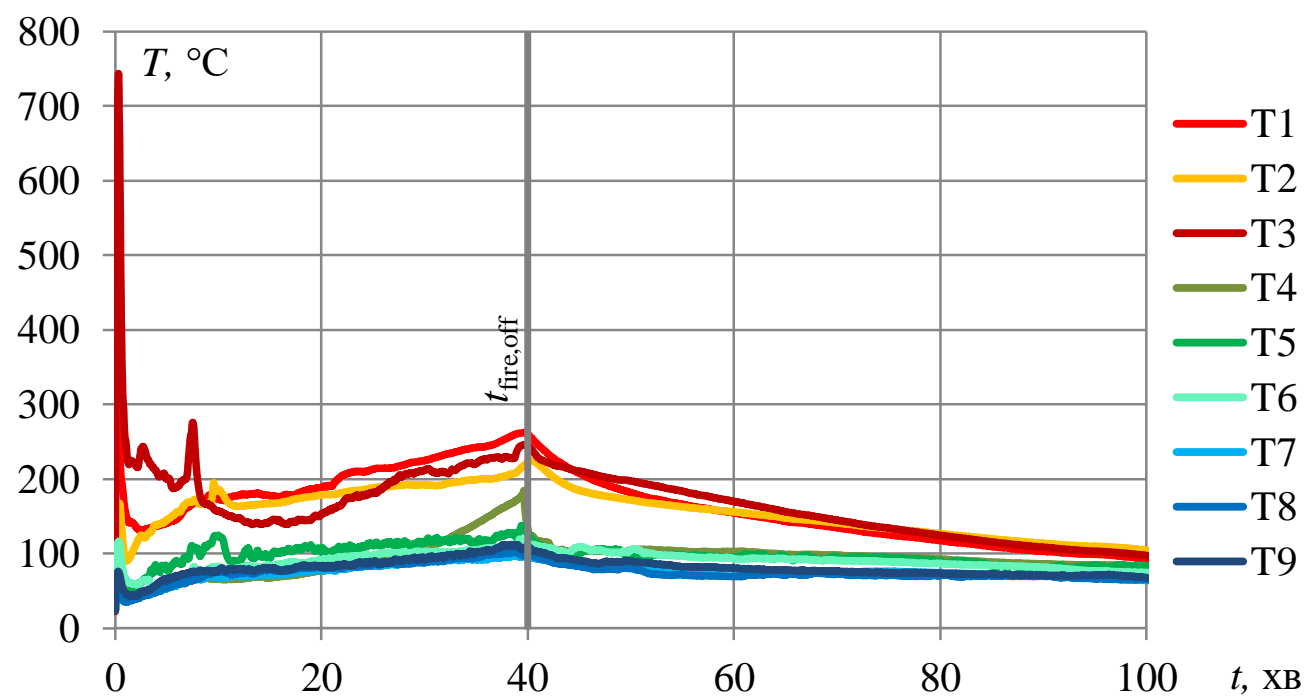

Рисунок 4. - Залежність температури газового середовища у різних місцях біля поверхні кабелів від тривалості випробування

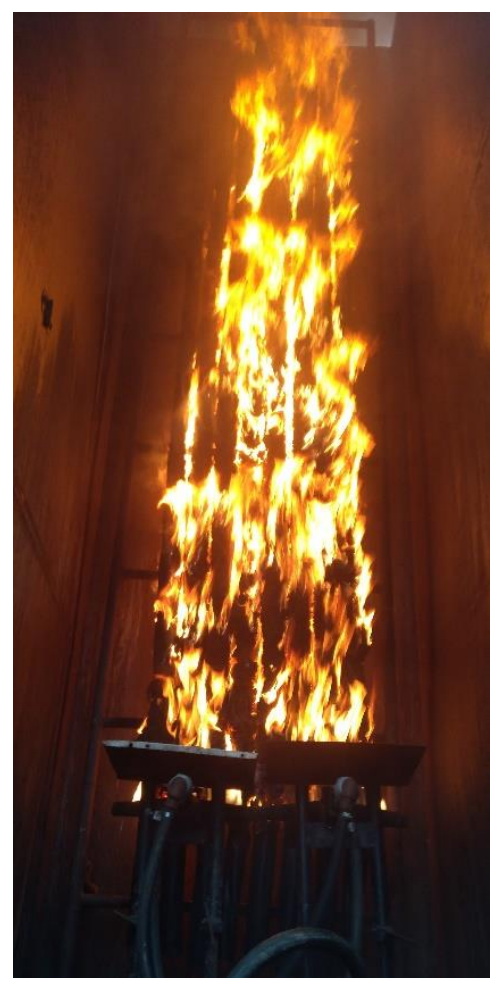

Рисунок 5 - Зовнішній вигляд кабелів на 30-ій хвилині випробування за ДСТУ ЕN 60332-3-22 [20]

У таблицях 1, 2 наведено експериментальні дані і результати визначення об'ємного коефіцієнту спучення за ДСТУ-Н-П Б В.1.1-29 [21] та вищої теплоти згоряння за ДСТУ Б EN ISO 1716 [22] реактивного вогнезахисного матеріалу «Ендотерм XT-150» [23]. Отримані результати визначення вищої теплоти згоряння та об'ємного коефіцієнту спучення оболонок кабелів, які застосовували при дослідженні стійкості до поширення полум'я, $\epsilon$ такими. Для кабелю марки АВВГ 4×185 вища теплота згоряння і об'ємний коефіцієнт спучення складають 16,81 МДж/кг та $2192 \mathrm{~mm}^{3} /$, а для кабелю марки АВБбШв $3 \times 150+1 \times 70$ - 19,12

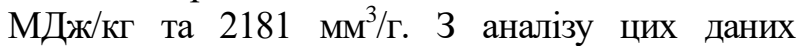
випливає, що значення об'ємного коефіцієнту спучення реактивного вогнезахисного матеріалу на порядок вище ніж у оболонок кабелів. Вища теплота згоряння реактивного вогнезахисного матеріалу на $27-36 \%$ нижча ніж у оболонок кабелів.

Таблиця 1 - Об’ємний коефіцієнт спучення реактивного вогнезахисного матеріалу «Ендотерм ХТ-150» 


\begin{tabular}{|c|c|c|c|c|c|}
\hline \multirow{2}{*}{$\begin{array}{c}\text { № аналітичної } \\
\text { проби }\end{array}$} & \multirow{2}{*}{$\begin{array}{c}\text { Маса } \\
\text { аналітичної } \\
\text { проби, г }\end{array}$} & \multicolumn{2}{|c|}{$\begin{array}{c}\text { Відстань між верхнім краєм стакана і } \\
\text { поверхнею матеріалу, мм }\end{array}$} & \multirow{2}{*}{$\begin{array}{c}\text { Середня } \\
\text { висота } \\
\text { спученого } \\
\text { шару, мм }\end{array}$} & \multirow{2}{*}{$\begin{array}{c}\text { Об'ємний } \\
\text { коефіцієнт } \\
\text { спучення } K_{\text {об, }} \text {, } \\
\text { мм }^{3} / \Gamma\end{array}$} \\
\hline & & до випробування & $\begin{array}{c}\text { після } \\
\text { випробування }\end{array}$ & & \\
\hline \multirow{5}{*}{1} & \multirow{5}{*}{3,0} & 68,7 & 26,4 & \multirow{5}{*}{46,02} & \multirow{10}{*}{23237} \\
\hline & & 69,8 & 22,1 & & \\
\hline & & 68,0 & 21,1 & & \\
\hline & & 68,3 & 23,4 & & \\
\hline & & 69,1 & 20,8 & & \\
\hline \multirow{5}{*}{2} & \multirow{5}{*}{3,0} & 69,5 & 21,6 & \multirow{5}{*}{45,72} & \\
\hline & & 69,9 & 23,8 & & \\
\hline & & 68,8 & 22,4 & & \\
\hline & & 69,3 & 25,3 & & \\
\hline & & 68,7 & 24,5 & & \\
\hline
\end{tabular}

Таблиця 2 - Вища теплота згоряння реактивного вогнезахисного матеріалу «Ендотерм XТ-150»

\begin{tabular}{|c|c|c|c|c|}
\hline $\begin{array}{c}\text { № аналітичної } \\
\text { проби }\end{array}$ & $\begin{array}{c}\text { Маса аналітичної } \\
\text { проби, г }\end{array}$ & $\begin{array}{c}\text { Вища теплота згорання } \\
\text { аналітичної проби, } \\
\text { МДж/кг }\end{array}$ & $\begin{array}{c}\text { Максимальне } \\
\text { відхилення, } \\
\%\end{array}$ & $\begin{array}{c}\text { Вища теплота згоряння } \\
\text { матеріалу } Q_{P C S}, \text { МДж/кг }\end{array}$ \\
\hline 1 & 0,25250 & 12,4010 & \multirow{2}{*}{2,58} & 12,27 \\
\hline 2 & 0,50445 & 12,3360 & 2,5805 & \\
\hline 3 & 0,25330 & 12,0805 & \\
\hline
\end{tabular}

Обговорення результатів дослідження стійкості до поширення полум'я кабелів, прокладених у металевому кабельному коробі. Як витікає 3 отриманих результатів, застосування реактивного вогнезахисного матеріалу на внутрішній поверхні металевого кабельного короба зменшує інтенсивність поширення полум'я по кабелях. Це обумовлено тим, що під час вогневого впливу на кабелі відбувається термічний розклад оболонок кабелів, займання i горіння газоподібних продуктів цього розкладу. Полум'я поширюється по висоті за межі отвору у кришці коробу, досягаючи його внутрішньої поверхні. Відбувається спучення реактивного вогнезахисного матеріалу 3 утворюванням теплоізоляційного шару, який досягає поверхні оболонок кабелів і перешкоджає поширенню полум'я по них. Цей процес спучення інтенсивно проходить протягом 1-2 хв від початку вогневого впливу на кабелі, про що свідчать експериментальні дані щодо температури газового середовища, наведені на рис. 4. У цьому часовому інтервалі на першій хвилині вогневого впливу відбувається інтенсивне підвищення температури газового середовища до $742^{\circ} \mathrm{C}$ на відстані 500 мм від пальників, що свідчить про наявність полум'я у зазначеній зоні. У подальшому протягом 1-2 хв спостерігається інтенсивне зменшення температури до $100-220^{\circ} \mathrm{C}\left(\mathrm{T}_{1}-\mathrm{T}_{3}\right.$, рис. 2,4$)$. Таке зменшення температури пояснюється утворенням теплоізоляційного шару в результаті спучення реактивного вогнезахисного матеріалу, яким покрито внутрішню поверхню короба. Через сформований теплоізоляційний шар відбувається теплопередача у вертикальному напрямку від полум'я пальників до поверхні цього шару, яка протилежна вогневому впливу. При цьому, протягом вогневого впливу тривалістю 40 хв, має місце монотонне незначне підвищення температури в коробі до максимального значення $262^{\circ} \mathrm{C}\left(\mathrm{T}_{3}\right.$, рис. 2,4$)$. У результаті такого температурного стану максимальна довжина обвугленої частини кабелів не перевищила граничного значення 1,5 м. Це свідчить про те, що зазначене конструктивне рішення щодо застосування реактивного вогнезахисного матеріалу на внутрішній поверхні металевого кабельного коробу прийнятне для забезпечення обмеження поширення вогню (полум'я) по кабелях в межах приміщення, де виникла пожежа.

Таке ствердження можна вважати за доцільне 3 практичної точки зору, тому що дозволяє обгрунтовано підходити до визначення конструктивних рішень, які забезпечують обмеження поширення полум'я по кабелях. Однак неможливо не відмітити, що результати проведеного дослідження мають певну невизначеність. Це проявляється, в першу чергу, в тому, що при дослідженні було застосовано кабельний короб тільки одного типорозміру i реактивний вогнезахисний матеріал тільки однієї марки. При використанні іншого 
кабельного коробу або реактивного вогнезахисного матеріалу, який має інші показники ніж ті, які наведено в таблицях 1 і 2 , не виключена можливість отримання неприйнятного результату щодо забезпечення стійкості до поширення полум'я. Можливість отримання такого ж результату неможна виключити і при застосуванні кабелів інших марок. Крім цього, не було досліджено інтенсивність поширення полум'я вздовж кабелів, прокладених у пучках у металевому коробі без вогнезахисного покриття. Неможливість зняти названі обмеження в рамках даного дослідження породжує потенційно цікавий напрям подальших досліджень. Вони, зокрема, можуть бути орієнтовані на виявлення впливу об'ємного коефіцієнту спучення реактивного вогнезахисного матеріалу, яким покрито внутрішню поверхню металевого кабельного коробу, i параметрів кабельного короба на стійкість кабелів до поширення полум'я. Таке виявлення дозволить визначити марки реактивних вогнезахисних матеріалів $\mathrm{i}$ параметри металевого кабельного коробу, прийнятні для забезпечення стійкості до поширення полум'я кабелів, прокладених у металевих коробах.

\section{Висновки}

1. Проведеними дослідженнями встановлено особливості процесу поширення полум'я по

\section{СПИСОК ЛІТЕРАТУРИ}

1. Regulation (EU) № 305/2011 of the European Parliament and of the Council of 9 March 2011 laying down harmonized conditions for the marketing of construction products and repealing Council Directive 89/106/EEC (Регламент (СС) № 305/2011 Європейського Парламенту та Ради від 9 березня 2011 року, що встановлює гармонізовані умови для розміщення на ринку будівельних виробів та скасовує Директиву Ради 89/106/EEC). - OJ L 88, 4.4.2011, p. 5-43.

2. Технічний регламент будівельних виробів, будівель і споруд. - Офіційний вісник України, 2006 р., № 51, ст. 3415.

3. ДБН В.1.2-7-2008 Система забезпечення надійності та безпеки будівельних об'єктів. Основні вимоги до будівель і споруд. Пожежна безпека.

4. ДСТУ 4809:2007 Ізольовані проводи та кабелі. Вимоги пожежної безпеки та методи випробування.

5. ДСТУ 4743:2007 Проводи самоутримні ізольовані та захищені для повітряних ліній електропередавання. Загальні технічні умови.

6. ВБН В.1.1-034-2003 (НАПБ 03.005-2002, ГНД 34.03.307-2004, ВБН B.1.1-034-03.307-2003) Противопожарные нормы проектирования атомных электростанций с водо-водяными энергетическими реакторами.

7. ДБН В.2.2-15-2005 Будинки i споруди. Житлові будинки. Основні положення. кабелях, прокладених у металевому кабельному коробі, внутрішня поверхня якого покрита реактивним вогнезахисним матеріалом. Ці особливості полягають у тому, що полум'я джерела запалювання і продукти горіння кабелів піддають тепловому впливу внутрішню поверхню короба, відбувається спучення реактивного вогнезахисного матеріалу 3 утворюванням теплоізоляційного шару, який досягає поверхні оболонок кабелів i перешкоджає поширенню полум'я по них. Сформований теплоізоляційний шар обмежує поширення вогню по коробу i зменшує інтенсивність теплопередачі від джерела запалювання.

2. Визначено конструктивне рішення, яке забезпечує обмеження поширення полум'я по кабелях, прокладених у металевому кабельному коробі, в межах приміщення, де виникла пожежа, яке полягає у покритті внутрішньої поверхні цього коробу реактивним вогнезахисним матеріалом.

3. Визначено напрям подальших досліджень, які орієнтовані на виявлення впливу об'ємного коефіцієнту спучення реактивного вогнезахисного матеріалу, яким покрито внутрішню поверхню металевого кабельного коробу, на стійкість кабелів до поширення полум'я, а також впливу параметрів металевого кабельного коробу, у тому числі без вогнезахисного покриття, на інтенсивність поширення полум'я вздовж кабелів.

8. ДБН В.2.5-23-2010 Інженерне обладнання будинків i споруд. Проектування електрообладнання об’єктів цивільного призначення.

9. Кулаков О. В. Електротехніка та пожежна профілактика в електроустановках: Навчальний посібник для студентів вищих навчальних закладів / О. В. Кулаков, В. О. Росоха - Харків: Академія пожежної безпеки України, 2003. - 362 с.

10. Правила з вогнезахисту, затверджені наказом Міністерства внутрішніх справ України № 1064 від 26.12.2018.

11. ДСТУ ЕN 60332-1-2:2017 (ЕN 60332-1-2:2004; A1:2015; A11:2016, IDT; IEC 60332-1-2:2004; A1:2015, IDT) Вогневі випробування електричних та волоконнооптичних кабелів. Частина 1-2. Випробування на вертикальне поширення полум'я одиничного ізольованого проводу чи кабелю. Метод випробування полум'ям попередньо змішаного типу потужністю 1 кВт.

12. ДСТУ ЕN 60332-1-3:2016 (ЕN 60332-1-3:2004, ЕN 60332-1-3:2004/A1:2015, IDT) Вогневі випробування електричних та волоконно-оптичних кабелів. Частина 1-3. Випробування на вертикальне поширювання полум'я одиничного ізольованого проводу чи кабелю. Метод визначення крапель/часток із запалювальною здатністю.

13. ДСТУ EN 60332-3:2013 (усі частини) Вогневі випробування електричних та волоконно-оптичних 
кабелів. Частина 3. Випробування вертикально розташованих проводів або кабелів, прокладених у пучках, на вертикальне поширювання полум'я (EN 60332-3 (all part), IDT)

14. Experimental studies of electrical cable fire response / Klapsa Wojciech, Bodalski Dawid, Suchecki Sylwester // By Wydawnictwo CNBOP-PIB BiTP. Vol. 35, Issue 3. 2014, Р. 97-105.

15. Каменский M. C. Основные аспекты пожарной безопасности электрических кабелей / М. К. Каменский // Кабель-news. - 2009. - № 6-7. - С. 61-67.

16. Burning behavior of cable tray located on a wall with different cable arrangements / Xianjia Huang, He Zhu, Lan Peng, Zihui Zheng, Wuyong Zeng // Fire and Materials. Vol. 43, Issue 1. 2019. P. 64-73.

17. Numerical simulations of a full-scale cable tray fire using small-scale test data / Tarek Beji, Bart Merci // Fire and Materials: Early View - Wiley Online Library. 2018. - 140 P.

18. EAD 350454-00-1104 Fire stopping and fire sealing products. Penetration seals (Матеріали та вироби для перешкоджання проникненню вогню і вогнезахисного заповнення. Проходки інженерних комунікацій).

\section{REFERENCES}

1. Regulation (EU) № 305/2011 of the European Parliament and of the Council of 9 March 2011 laying down harmonized conditions for the marketing of construction products and repealing Council Directive 89/106/EEC. OJ L 88, vol. 4.4.2011, pp. 5-43.

2. Tekhnichnyi rehlament budivelnykh vyrobiv, budivel i sporud. Ofitsiinyi visnyk Ukrainy, 2006, vol. 51,p 3415.

3. DBN V.1.2-7-2008 Systema zabezpechennia nadiinosti ta bezpeky budivelnykh obiektiv. Osnovni vymohy do budivel i sporud. Pozhezhna bezpeka.

4. DSTU 4809:2007 Insulated wires and cables. Fire safety requirements and test methods.

5. DSTU 4743:2007 Insulated and protected wires for overhead power lines General specifications.

6. VBN V.1.1-034-2003 (NAPB 03.005-2002, GND 34.03.307-2004, VBN V.1.1-034-03.307-2003) Protivopozharnye normy proektirovaniya atomnykh elektrostantsiy s vodo-vodyanymi energeticheskimi reaktorami.

7. DBN V.2.2-15-2005 Budynky i sporudy. Zhytlovi budynky. Osnovni polozhennia.

8. DBN V.2.5-23-2010 Inzhenerne obladnannia budynkiv i sporud. Proektuvannia elektroobladnannia obiektiv tsyvilnoho pryznachennia.

9. Kulakov O.V., Rosokha V.O. (2003) Elektrotekhnika ta pozhezhna profilaktyka v elektroustanovkakh: Navchalnyi posibnyk dlia studentiv vyshchykh navchalnykh zakladiv [Electrical engineering and fire prevention in electrical installations: A manual for students of higher educational establishments]. Kharkiv, Akademiia pozhezhnoi bezpeky Ukrainy, 362 p. (in Ukrainian)

10. Pravyla z vohnezakhystu, zatverdzheni nakazom Ministerstva vnutrishnikh sprav Ukrainy № 1064 vid 26.12.2018.

11. DSTU EN 60332-1-2:2017 (EN 60332-1-2:2004; A1:2015; A1 1:2016, IDT; IEC 60332-1-2:2004; A1:2015, IDT) Tests on electric and optical fibre cables under fire conditions Part 1-2: Test for vertical flame propagation for a single insulated wire or cable - Procedure for $1 \mathrm{~kW}$ premixed flame.

12. DSTU EN 60332-1-3:2016 (EN 60332-1-3:2004, EN 60332-1-3:2004/A1:2015, IDT) Tests on electric and optical fibre cables under fire conditions. Part 1-3. Test for
19. ДСТУ EN 60332-3-10:2013 Вогневі випробування електричних та волоконно-оптичних кабелів. Частина 3-10. Випробування вертикально розташованих проводів або кабелів, прокладених у пучках, на вертикальне поширювання полум я. Устатковання (EN 60332-3-10:2009, IDT).

20. ДСТУ EN 60332-3-22:2013 Вогневі випробування електричних та волоконно-оптичних кабелів. Частина 3-22. Випробування вертикально розташованих проводів або кабелів, прокладених у пучках, на вертикальне поширювання полум я. Категорія А (EN 60332-3-22:2009, IDT).

21. ДСТУ-Н-П Б В.1.1-29:2010 Захист від пожежі. Вогнезахисне обробляння будівельних конструкцій. Загальні вимоги та методи контролювання.

22. ДСТУ Б EN ISO 1716:2011 Випробування виробів щодо реакції на вогонь. Визначення вищої (нижчої) теплоти згорання (EN ISO 1716:2010, IDT).

23. ТУ У 24.3-13481691-007-2003 Суміш та покриття вогнезахисні спучені «Ендотерм ХТ-150». Технічні умови.

vertical flame propagation for a single insulated wire or cable. Procedure for determination of flaming droptets/particles, IDT

13. DSTU EN 60332-3:2013 Tests on electric and optical fibre cables under fire conditions Tests on electric and optical fibre cables under fire conditions Part 3-22 Test for vertical flame spread of vertically-mounted bunched wires or cables Category A (all part), IDT

14. Experimental studies of electrical cable fire response / Klapsa Wojciech, Bodalski Dawid, Suchecki Sylwester (2015) Wydawnictwo CNBOP-PIB BiTP, vol. 35, issue 3, pp. $97-105$.

15. Kamenskiy M. S. (2009) Osnovnye aspekty pozharnoy bezopasnosti elektricheskikh kabeley [Main aspects of fire safety electrical cables]. Kabel'-news, vol. 6-7, pp. 6167.(in Russian)

16. Xianjia Huang, He Zhu, Lan Peng, Zihui Zheng, Wuyong Zeng (2019) Burning behavior of cable tray located on a wall with different cable arrangements. Fire and Materials. vol. 43, Issue 1, pp. 64-73.

17. Tarek Beji, Bart Merci (2018) Numerical simulations of a full-scale cable tray fire using small-scale test data. Fire and Materials: Early View, Wiley Online Library, 140 p.

18. EAD 350454-00-1104 Fire stopping and fire sealing products. Penetration seals.

19. DSTU EN 60332-3-10:2013 Tests on electric and optical fibre cables under fire conditions Part 3-10. Test for vertical flame spread of vertically-mounted bunched wires or cables. Apparatus (EN 60332-3-10:2009, IDT).

20. DSTU EN 60332-3-22:2013 Tests on electric and optical fibre cables under fire conditions Part 3-22. Test for vertical flame spread of vertically-mounted bunched wires or cables. Category A (EN 60332-3-22:2009, IDT).

21. DSTU-N-P B V.1.1-29:2010 Zakhyst vid pozhezhi. Vohnezakhysne obrobliannia budivelnykh konstruktsii. Zahalni vymohy ta metody kontroliuvannia.

22. DSTU B EN ISO 1716:2011 Reaction to fire tests for products Determination of the gross heat of combustion (EN ISO 1716:2010, IDT).

23. TU U 24.3-13481691-007-2003 Sumish ta pokryttia vohnezakhysni spucheni «Endoterm KhT-150». Tekhnichni umovy 


\section{INCREASE THE CABLE RESISTANCE TO THE FLAME PROPAGATION THROUGH THE FACING OF THE METAL CABLE BOXE WITH REACTIVE FIRE PROTECTION MATERIAL}

S. Novak', Cand. of Sc. (Eng.), Senior Fellow, V. Drizhd ${ }^{2}$, Cand. of Sc. (Eng.), P.O. Illiuchenko ${ }^{1}$

${ }^{1}$ The Ukrainian Civil Protection Research Institute, Ukraine

${ }^{2}$ Scientific and production enterprise "Special materials", Ukraine

\section{KEYWORDS}

fire impact, cable, cable box, flame propagation, reactive fire protection material, swelling.

\begin{abstract}
ANNOTATION
To ensure compliance with the basic requirements for buildings and structures to limit the spread of fire in them during a fire, the provisions on the use of cables resistant to flame propagation at construction sites are given in building codes. To ensure this resistance, constructive solutions are used, which consist in the use of special plastics for cable sheathing or covering the surface of cables with fire protection materials. However, these constructive solutions are not always possible to implement in practice and the actual task is to identify other solutions that limit the spread of fire (flame) through cables within the room where the fire broke out, which is what the study in the article is dedicated to. During this study, the acceptability of a constructive solution was determined, which consists in the use of reactive fire protection material on the inner surface of a metal cable box, to ensure that the spread of flame through cables located in this box is limited. For the research, the methodology based on the provisions of DSTU EN 60332-3-10 and DSTU EN 60332-3-22 was applied. The essence of this technique lies in the fact that a bundle of category A cables, a class unstable to flame propagation, located inside a metal cable box, through a rectangular opening in the box cover for 40 minutes, is exposed to the flame of two special belt burners. After the termination of the impact of this flame, the length of the charred part of the cables is determined and compared with the boundary value, which is $1.5 \mathrm{~m}$. According to the results of the study, the peculiarities of the flame propagation process through cables laid in a metal cable box, the inner surface of which is coated with a reactive fire protection material, have been established. A constructive solution has been defined that limits the flame propagation through cables laid in a metal cable box within the room where the fire occurred. The direction of further research, which is focused on identifying the influence of the volume coefficient of expansion of the reactive fire protection material, which covered the inner surface of the metal cable box, on the resistance of the cables to flame propagation, has been established. These further studies are also focused on identifying the effect of the parameters of a metal cable box, including without a fire protection coating, on the intensity of flame propagation along the cables.
\end{abstract}

\section{ПОВЫШЕНИЕ СТОЙКОСТИ КАБЕЛЕЙ К РАСПРОСТРАНЕНИЮ ПЛАМЕНИ ПУТЕМ ОБЛИЦОВКИ МЕТАЛЛИЧЕСКОГО КАБЕЛЬНОГО КОРОБА РЕАКТИВНЫМ ОГНЕЗАЩИТНЫМ МАТЕРИАЛОМ}

С. В. Новак', канд. техн. наук, ст. научн. сотр., В. Л. Дрижд², канд. техн. наук, П. А. Иллюченко

'Украинский научно-исследовательский институт гражданской защиты, Украина

${ }^{2}$ Научно-производственное предприятие «Спецматериалы», Украина

\section{КЛЮЧЕВЫЕ СЛОВА}

огневое воздействие, кабель, кабельный короб, распространение пламени, реактивный огнезащитный материал, вспучивание.

\section{АННОТАЦИЯ}

Приведены результаты исследования стойкости к распространению пламени кабелей, проложенных в металлическом кабельном коробе, внутренняя поверхность которого покрыта реактивным огнезащитным материалом. Применена методика исследования, основанная на положениях ДСТУ ЕN 60332-3-10 и ДСТУ EN 60332-3-22. Сущность этой методики заключается в том, что на пучок кабелей категории A, класса нестойких к распространению пламени, расположенный 
внутри металлического кабельного короба, через прямоугольное отверстие в крышке короба в течение 40 мин воздействуют пламенем двух специальных ленточных горелок. После прекращения воздействия этого пламени определяют длину обугленной части кабелей и сравнивают ее с граничным значением, которое составляет 1,5 м. По результатам исследования установлено особенности процесса распространения пламени по кабелям, проложенным в металлическом кабельном коробе, внутренняя поверхность которого покрыта реактивным огнезащитным материалом. Определено конструктивное решение, которое обеспечивает ограничение распространения пламени по кабелям, проложенным в металлическом кабельном коробе, в пределах помещения, где возник пожар. Установлено направление дальнейших исследований, которые ориентированы на выявление влияния объемного коэффициента вспучивания реактивного огнезащитного материала, которым покрыто внутреннюю поверхность металлического кабельного короба, на стойкость кабелей к распространению пламени, а также влияния параметров металлического кабельного короба, в том числе без огнезащитного покрытия, на интенсивность распространения пламени вдоль кабелей. 